\title{
Investigation of the Relationship between Digital Game Addiction and English Listening Skills among University Students*
}

\author{
Ayşenur Ağaoğlu ${ }^{1}$
}

Erzincan Binali Yıldırım University, School of Foreign Languages, Erzincan, Turkey

\section{Süleyman Nihat Şad ${ }^{2}$}

Inönü University, Faculty of Education, Department of Educational Sciences, Malatya, Turkey

\begin{abstract}
The main aim of this study is to investigate the relationship between digital game addiction and English listening skills among university students. This quantitative associational research was conducted with 198 university students during the spring semester of 2018-2019 academic year. The data were collected using "Digital Game Addiction Scale" and "English Listening Skills Test". The results suggested that action, puzzle, and strategy games are the game categories most commonly played by the participants. Furthermore, it was found that $54 \%$ of the participants $(n=101)$ primarily played English games and they played 132.75 minutes per day on average. Participants' were moderately ( $\bar{x}=17.38 / 35 ; \quad s=6.91)$ to digital games. Their digital game addiction scores differed significantly by variables of gender and major. The mean score of the participants on the English listening skill test was 54.75/100. When the relationship among participants' level of digital game addiction, English listening skill, and average time (min.) to play English digital games a day was examined, it was found that as the daily time to play English digital games increased, the level of digital game addiction and English listening skills also increased.
\end{abstract}

\section{Suggested Citation:}

Ağaoğlu, A. and Şad, S.N. (2020). Investigation of the relationship between digital game addiction and English listening skills among university students. International Journal of Academic Research in Education, 6(1), 1-15. DOI: 10.17985/ijare.795676

\footnotetext{
1 Erzincan Binali Yıldırım University, aysenur.agaoglu@erzincan.edu.tr

2 Inönü University, nihat.sad@inonu.edu.tr
} 


\section{INTRODUCTION}

Playing games is one of the most important leisure time activities dating back to ancient times and occupying an important place in the lives of people, especially the children (Öztürk, 2007). Turkish Language Institution (TLA, 2019) describes game as "an act of entertainment with certain rules, which provides good time and develops talent and intelligence". Salen and Zimmerman (2003, p.77) describe game as "a voluntary activity which has a goal and involves rules". According to Prensky (2001), game is a multifaceted action that gives people pleasure, motivation, adaptability, power of interaction, problemsolving and learning abilities, a sense of competition and cooperation, creativity, and it is also an action that causes addiction by activating the motive of ambition. As one of the indispensable entertainment activities of all age groups, games allow people to explore their environment and the world, develop specific skills, and socialize (Bilgin, 2015). The game activities performed with real friends in real physical environments such as parks and streets in the past have gradually evolved into virtual activities performed on the internet today, i.e. digital games (Horzum, 2011).

One of the innovations of computer technology brought by the digital age is the concept of "digital game", which affects people of all ages (Erboy, 2010). The concept of digital gaming appears as "the sorts of video games in which the player takes on the role of a fantasy character moving through an elaborate world, solving various problems or in which the player builds and maintains some complex entity, like an army, a city, or even a whole civilization" (Gee, 2003, p. 1). While Vogel et al. (2006, p.231) describe digital games as "an activity which has goals, is interactive, and is rewarding (gives feedback)", Spires $(2015$, p.126) defines them as "multimodal texts with a combination of different communicative media, such as still and moving images, sound and music and speech and writing." Describing children born in the digital age as "digital natives," Prensky (2006) notes that the key elements of digital games attracting the most attention and interest are the nature of combat, competition, interaction with feelings such as challenge, and virtual reality. Digital games are programmed with various technologies and software and offer a visual environment to their users. Generally, users log into this environment by creating a virtual character. They can be played with multiplayers or single players based on the number of participants. These games are classified as console games, computer games, mobile or online games depending on the way they are programmed (Hazar and Hazar, 2017). Griffiths (2002) has listed digital games as racing games, adventure games, sports simulations, puzzles, platform games, fighting, and gun games according to their original qualities. Adams and Rollings (2006) divide digital games into seven categories: tactics, jigsaw, adventure, action, sports, role-playing, and simulation (as cited in Irmak \& Erdoğan, 2016).

The technological platforms used by the new generations in their daily lives have started to change the understanding of education. Müftüoğlu (2018) states that with technological developments, the perception of educators on educational environments has changed and technology now offers new opportunities for the improvement of educational environments. "Educational game" is one of the main student-centered methods that can enable students to actively participate in the learning process by increasing the student's intrinsic motivation (Şahin and Samur, 2017). Nowadays, the concept of educational game has evolved into a more comprehensive concept called "gamification", in which students will interact and collaborate more and can be used to improve their communication skills (Leipzig, Leipzig and Hummel, 2016). Gamification is the use of game components such as scores, awards, tasks, struggles and attainment of learning goals in order to engage students in the process to increase their motivation and create a student-centered learning environment (Banfield and Wilkerson, 2014). Garris, Ahlers and Driskell (2002) argue that through digital games, students actively participate in the learning environment and learn by structuring knowledge. 
Foreign Language Teaching is one of the fields where gamification is used extensively. One of the basic conditions of foreign language learning is to be exposed to that language and to communicate using the target language for a prolonged time. Educational games require students to use a foreign language while playing games and allow them to learn while having fun. Digital games are known to be quite useful in creating environments where a foreign language is useful and meaningful in classroom activities (Gömleksiz, 2005). In addition to the educational games used in planned and intentional foreign language courses within the scope of formal education, there are also digital games that individuals play outside the class as a leisure time activity. According to Prensky (2001), in these games, where the only purpose is to win the game, individuals can naturally learn new knowledge or skills. Most digital games require mutual communication with both virtual and real people. Since many international digital games are played in English, international players are encouraged to use English as a foreign language (Can \& Türkmen, 2017). Over the past two decades, individuals playing digital games, especially online multiplayer, have been reported to show improvements in foreign language. This has created a new field of research on the benefits of digital games in language learning and teaching (Müftüoğlu, 2018).

Previous studies reveal that the type and language of the digital games played matters in terms of the effects of digital games on students. Griffiths (2002) and Gros (2007) categorized digital games and suggested that action and simulation games require perception and motor ability, while strategy games require cognitive effort. Gee (2003) states that through game types such as action, strategy, and simulation, individuals learn many things on this occasion while integrating themselves with the characters and having fun in a virtual reality environment. Similarly, Csikszentmihalyi and Csikszentmihalyi (1998) investigated the effect of digital games played outside the classroom on students (as cited in Demirbilek and Yücel, 2017). According to the results of the study, they found that the students played digital games types such as simulation, strategy, and action only to win or level up the game, so they focused on the game very well and tried to fulfill the tasks in the game in the best way. Also, Kaptelinin and Cole (2002) note that the game types, which include elements of collaboration and communication, make positive contributions to individuals in learning foreign languages. Larsen-Freeman (2000), on the other hand, expresses the importance of digital games in a foreign language learning environment and states that the types of games that provide students with a real communication environment develop foreign languages. Besides, according to Johnson (2005), thanks to the digital game types that help to make decisions in the short and long term and include complex tasks students' foreign language usage areas and problem-solving skills improve. Furthermore, according to Aydın (2014), digital games played in a foreign language serve as a context for meaningful communication, and as the duration of digital games played in a foreign language increases, students actively participate in foreign language learning processes. Kaptelinin and Cole (2002) note that digital games, with a high rate of interaction between players, add a collaborative atmosphere to the foreign language learning environment, and lead students to communicate. It has attracted the attention of researchers that some types of digital games, designed as a simulation of real life, provide a serious opportunity to motivate people and learn foreign languages as well as the purpose of entertaining (Can \& Türkmen, 2017).

Prensky (2001) mentions that the players, whose only goal is to win the game, learn many things without realizing it, creating a new learning culture. Based on this statement of Prensky, it can be predicted that playing digital games, even sometimes at the level of addiction, implicitly contributes to foreign language acquisition. Also, it can be said that while playing these games, individuals are exposed to the foreign language and have to acquire verbal or written communication skills in order to complete the tasks given in the game, skip levels, win awards and have fun, even if the primary purpose is not to learn a foreign language. In this study, the main purpose is to investigate the relationship between playing digital games in their daily lives and the development of their English listening skills. Based on this main purpose, it is also aimed to describe their behaviors about playing digital games according to some variables. 


\section{Purpose of the study}

The main purpose of this study is to investigate the relations between participating university students' digital game addiction levels and English listening skills. It is also aimed to describe their behaviors regarding playing digital games including the category of digital games participants play, the language of the digital games, how long they play the digital games (especially in English) a day, and their digital game addiction levels. Moreover, it was analyzed whether their levels of digital game addiction differ significantly according to their gender and major. Based on these purposes, it was aimed to answer the following research questions:

1. What are the categories of digital games played by university students?

2. In what languages do university students play digital games?

3. How long do university students play digital games a day?

4. How long do university students play English digital games a day?

5. What is the level of digital game addiction among university students?

6. Do university students' levels of digital game addiction differ significantly according to their gender and major?

7. Are there any significant correlations among students' levels of digital game addiction, English listening skills and average time (min.) to play English digital games a day?

\section{METHOD}

\section{Research Design}

This research is designed in accordance with the quantitative associational model. In associational designs, it is aimed to examine the relationships between two or more variables from the data obtained (Büyüköztürk et al. 2008). In this study, the digital game addiction levels and English listening skills of the students was investigated. Accordingly, in the study, first, the participants were described regarding the category of digital games they play, the language they play the digital games, how long they play digital games (especially in English) a day, and their digital game addiction levels; and secondly the relations between participants' digital game addiction levels and such variables as gender, major, and English listening skills were investigated.

\section{Study Group}

This study was conducted in a higher education institution in Eastern Anatolia with 198 students during the spring term of 2018-2019 academic year. No sampling was performed as all of the students were accessed. The determination of the participants in the study was made on a voluntary basis. Necessary permissions to carry out the study were obtained from the relevant authorities and the data collection tool was administered to the students by the first researcher. The demographic characteristics of the students participating in the study are presented in Table 1. 
Table 1. Information about participants

\begin{tabular}{llll}
\hline Variables & & $\mathrm{N}$ & $\%$ \\
\hline Gender & Female & 99 & 50.0 \\
& Male & 99 & 50.0 \\
\hline \multirow{3}{*}{ Department } & Lecorative and Craft Arts & 44 & 22.2 \\
& Restoration and Architecture & 21.2 \\
& Tourism Management and Hospitality & 49 & 31.8 \\
\hline \multirow{3}{*}{ Grade } & Year 1 & 63 & 24.7 \\
& Year 2 & 85 & 42.9 \\
& Year 3 & 78 & 39.4 \\
& Year 4 & 16 & 8.1 \\
\hline Age & & 19 & 9.6 \\
\hline
\end{tabular}

As it is seen in Table 1, it is observed that participants are distributed according to three different variables. In this study, students were involved from four different departments and class levels at the undergraduate level.

\section{Data Collection Tools}

The data was collected by demographic information form, "Digital Game Addiction Scale" and "English Listening Skill Test". The data collection tool was distributed to 200 students in total by the researcher, and all of them returned. After the missing and incorrect ones were removed from these returns, the remaining 198 students' data were used in the analysis.

\section{Digital Game Addiction Scale}

In order to measure the level of digital game playing of the participants, Digital Game Addiction Scale, which was developed by Lemmens, Valkenburg and Peter (2009) and adapted into Turkish by Irmak and Erdoğan (2015), was used. The scale is the 7-item short form of the DOB-21 scale consisting of 21 items under 7 sub-scales. This 5 -point ( 1 =never 5 =always) Likert type scale produces total scores between 7 and 35. In the adaptation study conducted by Irmak and Erdoğan (2015), the Cronbach Alpha internal consistency coefficient of the scale was found 0.72 , the total item correlation coefficients were estimated between $0.52-0.76$, and the test-retest reliability coefficient was 0.80 . In the explanatory factor analysis, the scale explained $56.96 \%$ of the total variance under a single factor and the factor loadings ranged between 0.52 and 0.77 , while the confirmatory factor analysis revealed favorable goodness of fit values $[X 2=14.22, p=0.37, d f=14, R M S E A=0.012, A G F I=0.92, C F I=0.99, G F I=0.96$ and SRMR=0.06] (Irmak and Erdoğan, 2015). In this study, the Cronbach Alpha internal consistency coefficient calculated on the data set of 198 people was found 0.873 . The data collection tool also involved students' personal information about their gender, age, department, and grade levels, and the three digital games they played the most in the last 6 months, the average minutes they played these games per day, and the language they played the games. 


\section{English Listening Skill Test}

A set of 20 questions at B1 level selected from among the sample Preliminary English Test (PET), provided by Cambridge English (ESOL) (2019) website, was used to measure students' listening skills. The validity and reliability indicators of the 20-item listening test were estimated using the data set obtained from the 198 students who participated in the study. Accordingly, the data were subjected to item difficulty, item discrimination and KR20 internal consistency analyses with Test Analysis Program (TAP, Version 14.7.4) (Brooks \& Johanson, 2003) software. According to the results of the analysis, the average difficulty level of 20 items in the listening test was 0.549 ( $\min$. score $=0$ and max. score $=100$ ), the average distinctiveness level was 0.506 ( $\min .=0.26$ and $\max =0.72$ ), and the mean of total item correlation coefficient was 0.452 ( $\min .=0.28$ and $\max .=0.59$ ) and $\mathrm{KR} 20$ internal consistency coefficient was calculated as 0.796 . These values indicated that the structure of the listening test was valid, and the scores obtained from the test were reliable.

\section{Data Analysis}

The scale and English listening test were applied to the participants. After the data was transferred to the computer, the data were analyzed with SPSS program. In descriptive analysis of the study, frequency, percentage, mean and standard deviations were calculated. In this direction, the answers given by the participants about the digital games they played were classified and presented in categories in line with the research questions.

Prior to the inferential analysis, the data sets were examined in terms of normality assumption. As a result, skewness and kurtosis statistics were found between \pm 1 across the subgroups of variables, indicating tolerable deviation from normality. For the difference analysis, independent samples $t$ test and one-way ANOVA tests were used, while the correlation analysis was done using Pearson analysis. Significance level was set to $p<.05$.

\section{FINDINGS}

\section{Distribution of the Categories of Digital Games Played by Participants during the Last Six Months}

In the research, participants were asked to write down the names of three games they played most during the last 6 months. These games were categorized according to the game types such as action, war, educational puzzle, and their frequency and percentages were calculated by the researchers. The distribution of the games by categories is given in Table 2 . 
Table 2. Distribution of the Categories of Digital Games Participants Played the Most during the Last Six Months

\begin{tabular}{|c|c|c|c|c|c|c|c|c|}
\hline \multicolumn{3}{|c|}{ Most Played Game \#1 } & \multicolumn{3}{|c|}{ Most Played Game \#2 } & \multicolumn{3}{|c|}{ Most Played Game \#3 } \\
\hline Category & $f$ & $\%$ & Category & $f$ & $\%$ & Category & $f$ & $\%$ \\
\hline Action & 72 & 36.4 & Not playing & 113 & 57.1 & Not playing & 159 & 80.3 \\
\hline Not playing & 37 & 18.7 & Puzzle & 13 & 6.6 & War & 6 & 3.0 \\
\hline Puzzle & 23 & 11.6 & Strategy & 13 & 6.6 & Puzzle & 6 & 3.0 \\
\hline Strategy & 19 & 9.6 & Action & 13 & 6.6 & Educational & 6 & 3.0 \\
\hline Educational & 12 & 6.1 & Fun & 12 & 6.1 & Simulation & 5 & 2.5 \\
\hline Simulation & 11 & 5.6 & Educational & 10 & 5.1 & Strategy & 5 & 2.5 \\
\hline War & 6 & 3.0 & War & 9 & 4.5 & Role playing & 3 & 1.5 \\
\hline Race & 6 & 3.0 & Sport & 5 & 2.5 & Race & 3 & 1.5 \\
\hline Fun & 5 & 2.5 & Race & 4 & 2.0 & Fun & 2 & 1.0 \\
\hline Sport & 4 & 2.0 & Role playing & 5 & 2.5 & Sport & 2 & 1.0 \\
\hline Role playing & 3 & 1.5 & Simulation & 1 & 0.5 & Action & 1 & 0.5 \\
\hline Total & 198 & 100 & Total & 198 & 100 & Total & 198 & 100 \\
\hline
\end{tabular}

As shown in Table 2, 37 participants (18.7\%) stated that they did not play any digital games. On the other hand, for the first game, $36,4 \%$ of the participants ( $f=72)$ were found to play action games, $11.6 \%(f=23)$ played puzzle games, and \%9,6 $(f=19)$ played strategy games, 6.1\% ( $f=12)$ educational games, $\% 5,6(f=11)$ simulation games, $3 \%(f=6)$ war games, $3 \%(f=6)$ race games, $2.5 \%(f=5)$ fun games, $2 \%(f=4)$ sports games and $1.5 \%(f=3)$ played role-playing games. About the second most played games of the participants, $57.1 \%$ of the participants $(f=113)$ stated that they did not play a second game in the last six months. However, 13 students (6.6\%) stated to play puzzle, action, and fun games the most as a second game, followed by educational games (5.1\%) and war games (4.5\%). When looking at the categories of the third games the students played most, $80.3 \%$ of the students $(n=159)$ did not play a third game. Among the remaining students, the most played games were war, puzzle, and educational games with a ratio of $3.0 \%$ $(f=6)$. Based on these findings, it can be said that the digital games that the students played most in the last six months are action, puzzle, and strategy games, respectively. The most commonly played action games among the participants were Pubg, Rope Hero, Crysis, Free Fire and NOVA; In the category of puzzle games, there are games like Word Game, Candy Crash, Trivia Crack, Puzzle Game; In the category of strategy games are Vain Glory, Last Island, Clash of Clans, LOL, Mobile Legends, Arena of Evolution.

\section{Distribution of the Languages of the Digital Games Played by Participants during the Last Six Months}

In order to understand the effective of playing the digital games on English listening skills, the participants were also asked in which languages they played the digital games. The distribution of digital games played by participants in the last six months by language is given in Table 3 . 
Table 3. Distribution of Digital Games Played by Participants in The Last Six Months By Language

\begin{tabular}{|c|c|c|c|c|c|c|c|c|}
\hline \multicolumn{3}{|c|}{ Most Played Game $1^{\text {st }}$} & \multicolumn{3}{|c|}{ Most Played Game $2^{\text {nd }}$} & \multicolumn{3}{|c|}{ Most Played Game $3^{\text {rd }}$} \\
\hline Game language & $f$ & $\%$ & $\begin{array}{l}\text { Game } \\
\text { language }\end{array}$ & $f$ & $\%$ & $\begin{array}{l}\text { Game } \\
\text { language }\end{array}$ & $f$ & $\%$ \\
\hline English & 107 & 54 & Not playing & 113 & 57.1 & Not playing & 159 & 80.3 \\
\hline Turkish & 52 & 26.3 & English & 51 & 25.8 & English & 24 & 12.1 \\
\hline Not playing & 37 & 18.7 & Turkish & 32 & 16.2 & Turkish & 15 & 7.6 \\
\hline \multirow[t]{2}{*}{ Russian } & 2 & 1.0 & Arabic & 1 & 0.5 & & & \\
\hline & & & Russian & 1 & 0.5 & & & \\
\hline Total & 198 & 100 & Total & 198 & 100 & Total & 198 & 100 \\
\hline
\end{tabular}

As shown in Table 3, the language of the primary digital game, which $54 \%$ of the participants $(f=107)$ played most in the last six months, is English. Only 26.3\% ( $f=52)$ of the participants stated that the language of the primary game they played most was Turkish and only two students played their primary digital game in Russian (1\%). When asked the second most played game, $25.8 \%(f=51)$ of the participants stated that they played English games and $16.2 \%(f=32)$ reported that they played Turkish games. When asked the third game they played most, $12.1 \%(f=24)$ of the participants stated that they played English games, while only $7.6 \%(f=15)$ reported that they played Turkish games. Accordingly, it can be said that the languages of the digital games most commonly played by the participants are English and Turkish, respectively. On the other hand, Russian and Arabic digital games are played very few.

\section{Participants' Daily Average Duration of Playing Digital Games}

Within the scope of the research, the students were also asked how long (minutes) they played digital games per day in the last six months. The minimum-maximum values and mean-standard deviation values of the answers are given in Table 4.

Table 4. Participants' Daily Average Duration of Playing Digital Games in the Last Six Months (Minute)

\begin{tabular}{llllll}
\hline Time (Minute/Day) & N & Min. & Max & $\bar{x}$ & S \\
\hline Duration of $1^{\text {st }}$ Game & 161 & 5 & 840 & 132.75 & 112.81 \\
Duration of $2^{\text {nd }}$ Game & 85 & 10 & 240 & 86.57 & 53.97 \\
Duration of $3^{\text {rd }}$ Game & 39 & 15 & 180 & 67.80 & 42.74 \\
\hline
\end{tabular}

When the duration of playing is examined, it is seen that 161 people who play digital games spend an average of 132.75 minutes (min.-max $=5-840$ minutes) in a day for the first game they play most. The average daily time spent on the second game by 86 participants who declared to play a second game is 86.57 minutes (min.-max $=10-240$ minutes). For the third game, the maximum time spent by 39 participants was 180 minutes, the minimum time was 15 minutes and the average time was 67.80 minutes. 


\section{Participants' Daily Average Duration of Playing Digital Games in English}

In order to calculate how long (minutes) the participants played English digital games each day; the average daily duration of the English-only games was taken within the three games that students played the most. For those who did not play or not played in English, this period is considered to be zero. The results of the descriptive analysis of the participants' total daily duration of playing in English are given in Table 5.

Table 5. Participants' Daily Average Duration of Playing Digital Games in English (Minute)

\begin{tabular}{lllll}
\hline $\mathrm{N}$ & Min. & Max. & $\overline{\mathrm{x}}$ & $\mathrm{s}$ \\
\hline 198 & 0 & 840 & 109.10 & 154.50 \\
\hline
\end{tabular}

As a result of the descriptive analysis, it was found that the daily average playing time in English of 198 participants was 109.10 minutes (min.-max. $=0-840$ minutes) a day.

\section{Participants' Level of Digital Game Addiction}

Table 6 shows the minimum-maximum values and mean, standard deviation values of the scores obtained from the "Digital Game Addiction" scale.

Table 6. Descriptive Statistics on Participants ' Digital Game Addiction

\begin{tabular}{llllll}
\hline Variable & N & Min. & Max. & $\bar{x}$ & $s$ \\
\hline Digital Gaming Level & 198 & 7.00 & 35.00 & 17.38 & 6.91 \\
\hline
\end{tabular}

The mean score of the participants on the 7-item digital game addiction scale with the lowest score of 7 and the highest score of 35 was 17.38 ( $s=6.91)$. From this point of view, it can be said that the digital game addictions of the participants are medium level.

\section{Investigation of Digital Game Addiction Levels in Terms of Different Variables}

The results of the independent sample $T$ test for comparing the digital game addiction levels of male and female students are given in Table 7.

Table 7. T Test Results Based on Gender Variable of Participants' Digital Game Addiction Levels

\begin{tabular}{lllllll}
\hline Group & $N$ & $\bar{X}$ & Ss & Sd & t & $p$ \\
\hline Female & 99 & 15.87 & 6.67 & \multirow{2}{*}{196} & -3.143 & $.002^{*}$ \\
Male & 99 & 18.89 & 6.85 & & & \\
\hline
\end{tabular}

$* p<.05$

According to the results of $t$ test, a statistically significant difference was found between male and female students in terms of digital game addiction levels in favor of male students $[t(196)=-3.143, p<.05]$. Accordingly, digital game addiction levels of male students $(\bar{X}=18.89)$ were found to be significantly higher than that of female students $(\bar{X}=15.87)$. According to the calculated Cohen $d$ value $(d=0.46)$, it can be said that the effect size of this difference is medium and meaningful in practice, as well. 
One-way ANOVA results are given in Table 8 to determine whether the students' digital game addiction levels differ significantly according to the department variable.

\begin{tabular}{|c|c|c|c|c|c|c|c|c|c|}
\hline Digital Game Addiction & $\mathrm{N}$ & $\bar{x}$ & $S$ & $\begin{array}{l}\text { Source of } \\
\text { variance }\end{array}$ & $\begin{array}{l}\text { Sum of } \\
\text { squares }\end{array}$ & $\mathrm{df}$ & $\begin{array}{l}\text { Mean } \\
\text { square }\end{array}$ & $\mathrm{F}$ & $p$ \\
\hline A) Decorative and Craft Arts & 44 & 14.45 & 5.63 & $\begin{array}{l}\text { Between } \\
\text { groups }\end{array}$ & 769 & 3 & 256.33 & 5.75 & $.001^{*}$ \\
\hline $\begin{array}{l}\text { B) Laboratory Assistant and } \\
\text { Veterinary Health }\end{array}$ & 42 & 18.67 & 7.00 & $\begin{array}{l}\text { Within } \\
\text { groups }\end{array}$ & 8639.59 & 194 & 44.53 & & \\
\hline C) Restoration \& Architecture & 63 & 16.67 & 7.31 & Total & 9408.59 & 197 & & & \\
\hline D) Tourism Management & 49 & 19.81 & 6.37 & & & & & & \\
\hline Total & 198 & 17.38 & 6.91 & & & & & & \\
\hline
\end{tabular}

Levene $(3 ; 194)=1.189, p<.05$

$* p<.05$

As a result of One-way ANOVA test, it was observed that the digital game addiction levels of the students studying in different departments differed significantly, $F(3 ; 194)=6,234 ; p<.05$. The Eta Square effect size value for this difference was calculated as $\eta^{2}=0.081$. Accordingly, approximately $8 \%$ of the variance observed in students' level of digital game addiction is due to the department variable. As a result of posthoc Bonferroni test conducted to find out the difference between the groups, the level of digital game addiction of Decorative and Craft students $(\bar{x}=14.45)$ was significantly lower than both Laboratory Assistant and Veterinary Health students $(\bar{x}=18.67)$ and Tourism Management and Hospitality students $(\bar{x}=19.81)$.

\section{Participants' Levels of English Listening Skill}

The descriptive results of the participants' scores from the "English Listening Skill" test are given in Table 9.

Table 9. Descriptive Statistics on Participants' English Listening Skill Levels

\begin{tabular}{llllll}
\hline Variable & $\mathrm{N}$ & Min. & Max. & $\overline{\mathrm{x}}$ & $\mathrm{s}$ \\
\hline English Listening Skill & 198 & .00 & 20.00 & 10.97 & 4.34 \\
\hline
\end{tabular}

The average of the correct answers given to the 20-question test was 10.97 ( $s=4.34$ ). Considering that this value corresponds to $54.75 \%$ success, students' listening skills in English can be said to be at a moderate level.

\section{Relationship between Participants' Level of Digital Game Addiction, English Listening Skills and Total Duration of Playing}

To answer the last research question of the study, it was examined whether there is a significant relationship between the levels of digital game addiction, English listening skills and total duration of playing English digital games by students. The results of Pearson correlation analysis are given in Table 10. 
Table 10. The Results of Relationship Analysis between Participants' Level of Digital Game Addiction, English Listening Skills and Total Duration of Playing English Games

\begin{tabular}{|c|c|c|c|c|}
\hline Variable & & $\begin{array}{c}\text { Level of Digital Game } \\
\text { Addiction }\end{array}$ & $\begin{array}{c}\text { English } \\
\text { Listening Skills }\end{array}$ & $\begin{array}{c}\text { Total Duration of } \\
\text { Playing English } \\
\text { Games }\end{array}$ \\
\hline \multirow{3}{*}{$\begin{array}{l}\text { 1) Level of Digital } \\
\text { Game Addiction }\end{array}$} & $r$ & 1 & ,404* & ,500* \\
\hline & $p$ & & ,000 & ,000 \\
\hline & $\mathrm{n}$ & 198 & 198 & 198 \\
\hline \multirow[t]{3}{*}{ 2) English Listening Skills } & r &, $404^{*}$ & 1 & ,495* \\
\hline & $\mathrm{p}$ &, 000 & &, 000 \\
\hline & $\mathrm{n}$ & 198 & 198 & 198 \\
\hline \multirow{3}{*}{$\begin{array}{l}\text { 3) Total Duration of Playing } \\
\text { English Games }\end{array}$} & $r$ &, $500^{*}$ & ,495* & 1 \\
\hline & $p$ & ,000 & ,000 & \\
\hline & $\mathrm{n}$ & 198 & 198 & 198 \\
\hline
\end{tabular}

$* P<.05$

As can be seen in Table 10, Pearson correlation analysis showed that there was a moderate significant positive correlation between the level of digital game addiction and English Listening Skill $(r=0,404)$ and the total duration of playing in English $(r=0,500)$. In addition, a moderate significant positive correlation was found between the total duration of playing English games and English Listening Skill $(r=0,495)$. These findings indicate that as the students' duration of playing digital games increases, their digital game addiction levels increase and English listening skills improve. From this point of view, it can be concluded that university students' playing digital games in English is related to the development of English listening skills, despite the risk of addiction.

\section{DISCUSSION \& CONCLUSION}

In this study, it was aimed to first describe participating university students' behaviors regarding playing digital games and secondly the relations between participants' digital game addiction levels and such variables as gender, major, and English listening skills were investigated within the context of a higher education institution in Eastern Anatolia.

When the games written by the students were analyzed and categorized, it was seen that the genre of the games most played was action games with a rate of $43.5 \%$ ( $n=86$ ). On the other hand, the distribution of digital games played by the participants in the last six months according to their languages was examined. The participants' English language usage rate for the first game they preferred was 54\%; for the second most played game, it was $28.8 \%$ and for the third most played game, it was $12.1 \%$. According to these results, the majority of participants were observed to play digital games in the English language.

In order to measure the frequency of playing digital games, participants were asked how long (minutes) they played digital games. When the results were analyzed, the participants' maximum time spent was 840 minutes, the minimum time spent was 5 minutes and the average time spent was 90 minutes. Afterward, it was examined whether the level of digital game addiction differed according to gender variable. According to the results of the analysis, it was observed that the level of digital game addiction 
of male students was higher than female students. Ko et al. (2005) stated that playing digital games is more common among men than women, and game addiction is also higher in men than women. Games are generally produced by men and for men. They mostly contain a masculine image and women stay away from games with harshness and aggression. Also, men get higher scores in games and they desire to continue playing (Griffiths and Davies, 2005). These can be seen as the reasons that push men to play more than women. Besides, it was seen that the levels of digital game addiction of the students studying in different departments differed significantly. It was concluded that the level of digital game addiction of Tourism Management and Hospitality students was significantly higher than the other departments. Since the students in this department are more exposed to a foreign language due to their courses, they are not only limited to games in their own language but also have the opportunity to play games in a foreign language. As the variety of games played by these students increases, game addiction levels may increase as well.

As a result of the correlation analysis conducted to determine whether there is a significant relationship between the levels of digital game addiction, English listening skills and the total duration of playing digital games of the students; the findings indicate that both students' digital game addiction levels and their English listening skills increase as their duration of playing digital games increases. From this point of view, it can be concluded that university students' playing digital games in English is related to the development of English listening skills.

Supporting this study Aydın (2014) mentions that digital games that people play outside of the classroom in line with their own interests and desires provide positive communication skills in language education. Gömleksiz (2005) mentions that digital games, whose main purpose is to entertain individuals, facilitate the acquisition of foreign languages because they provide a more comfortable and pleasant environment, and make it permanent. When people play these games, their goal is not to learn a foreign language, but to complete the tasks given within the game, skip level, win awards, and have fun. However, as a result of this research, individuals exposed to foreign language while playing digital games can be said to have acquired some skills in foreign language. Especially the individuals who gain vocabulary and listening skills, the foreign language is developing unwittingly thanks to digital games. In this case, there is a significant relationship between English language skills and the digital games played in the English language subject to the research.

In this study, the results provide guidance to researchers and practitioners studying in the field of Education. Based on the findings, some suggestions can be made to foreign language teachers. For example, in order to integrate digital games with the educational environment, in-class and out-of-class activities can be carried out. With these activities used in the classroom, the course content can be enriched by adding different digital games to the foreign language units to attract the attention of the students. In addition, the technologies used in the digital gaming platforms can be compared with the technologies used in the field of education to intensify and develop foreign language education. In this way, digital games can be developed that will attract students' interest and, at the same time, improve their foreign language skills in parallel to the curriculum. On the other hand, although it develops language skills based on the relationship between digital game addiction and English listening skills, studies can be conducted to identify games with inconvenient or potentially dangerous content (violence, betting, etc.) that children and young people should avoid. 


\section{References}

Aydın, T. (2014). Language teaching and games -in the light of multiple intelligence theory. Dilbilimleri Akademik Araştırma Dergisi, 14(1), 71-83.

Banfield, J. and Wilkerson, B. (2014). Increasing student intrinsic motivation and self-efficacy through gamification pedagogy. Contemporary Issues in Education Research - Fourth Quarter, 7(4), 291-198.

Bilgin, C. (2015). The relationships between computer game addiction level of junior high school students and their communication skills. Unpublished Master's Thesis, Pamukkale University Educational Sciences Institute, Denizli.

Büyüköztürk, Ş., Kılıç-Çakmak, E., Akgün, Ö. E., Karadeniz, Ş., and Demirel, F. (2008). Scientific research methods. Ankara: Pegem Akademi.

Cambridge English (ESOL) (2019). Preliminary English Test (PET). Retrieved from https://www.examenglish.com/cambridge_esol.php

Can, M. Z. and Türkmen, B. (2017). Study on the contribution of computer games to the foreign language education: research sample on 100 higher education students whose native languages is Turkish. Tarih Okulu Dergisi, 31, 399-435.

Demirbilek, M. and Yücel Z. (2011). English language teachers' perspectives on using computer games for second language teaching and learning. Eğitim Fakültesi Dergisi, 24(1), 217-246.

Erboy, E. (2010). The factors which effect on computer game addiction of 4th and 5 th grade primary students. Unpublished Master's Thesis, Adnan Menderes University Social Sciences Institute, Aydın.

Fraenkel, J. R., Wallen, N. E. \& Hyun, H. H. (2012). How to design and evaluate research in education (8th edition). New York, USA: McGraw-Hill.

Garris, R., Ahlers, R. and Driskel J. E. (2002). Games, motivation, and learning: a research and practice model. Simulation \& Gaming, 33(4), 441-466.

Gee, J.P. (2003). What video games have to teach us about learning and literacy. ACM Computers in Entertainment, 1(1), 1-4.

Gömleksiz, M. N. (2005). Implementation of English teaching with games and its effect on student success. Fırat Üniversitesi Sosyal Bilimler Dergisi, 32, 180-195.

Griffiths, M. D. (2002). The educational benefits of videogames. Education and Health 4, 20(3), 47-51.

Griffiths, M.D. and Davies, M.N.O. (2005). Videogame addiction: Does it exist? In J. Goldstein and J. Raessens (Eds.), Handbook of computer game studies (p. 359-368). Boston: MIT.

Gros, B. (2007). Digital games in education: The design of games-based learning environments. Journal of Research on Technology in Education, 40(1), 23-38.

Hazar, Z. and Hazar, M. (2017). Digital game addiction scale for children. Journal of Human Sciences, 14(1), 204-215. 
Horzum, M. B. (2011). Examining computer game addiction level of primary school students in terms of different variables. Eğitim ve Bilim Dergisi, 36(159), 56-68.

Irmak, A. Y. and Erdoğan, S. (2015). Digital game addiction among adolescents and younger adults: a current overview. Türk Psikiyatri Dergisi, 27(2), 128-137.

Johnson, S., (2005). Everything bad is good for you: How today's popular culture is actually making us smarter. London: Allen Lane.

Kaptelinin, V., and Cole, M. (2002). Individual and collective activities in educational computer game playing. In T. Koschmann \& R. Hall (Eds.), CSCL2 Carrying Forward the Conversation (pp.303-316). Mahwah, NJ: Lawrence Erlbaum As Sociates Inc.

Ko, C.H., Yen, J.Y., Chen, C.C., Chen, S.H. and Yen, C.F. (2005). Gender differences and related factors affecting online gaming addiction among Taiwanese adolescents. Journal of Nervous and Mental Disease, 193(4), 273-277.

Larsen-Freeman, D. (2000). Techniques and principles in language learning. (2nd ed.) Oxford: Oxford University Press.

Leipzig, T., Leipzig, K. H. \& Hummel, V. (2016). Gamification: teaching within learning factories. In Competitive Manufacturing, International Conference on Competitive Manufacturing, 467-464.

Lemmens J.S., Valkenburg P.M., and Peter J. (2009). Development and validation of a game addiction scale for adolescents. Media Psychol, 12(1), 77-95.

Müftüoğlu, A.C. (2018). Turkish efl pre-service teachers' attitudes toward and reflections on digital game enhanced practice. Unpublished Master's Thesis, Çukurova University Institute of Social Sciences, Adana.

Öztürk, D. (2007). A study of the effects of computer games on children's cognitive and affective development. Unpublished Master's Thesis, Dokuz Eylül University Social Sciences Institute, İzmir.

Prensky, M. (2001). Fun play and games: What makes games engaging. Digital Game-Based Learning, 5, 105.

Prensky, M. (2006). Don't bother me, Mom, I'm learning!: How computer and video games are preparing your kids for 21 st century success and how you can help!. St. Paul, MN: Paragon house.

Salen, K. and Zimmerman, E. (2003). Rules of play: game design fundamentals. London: Cambridge Massachussets The Mit Press. Retrieved from https://bit.ly/2MhVJ9z

Spires, H. (2015). Digital game-based learning: what's literacy goy to do with it? Journal of Adolescents and Adult Literacy, 59(2), 125-130.

Şahin, M. and Samur, Y. (2017). Instructional method of digital age: gamification. Journal of Ege Education Technologies, 1(1), 1-27.

TLA (Turkish Language Association) (2019). General Annotated Dictionary. Retrieved from https://sozluk.gov.tr/ 
Vogel, J. J., Vogel, D. S., Cannon-Bowers, J., Bowers, C. A., Muse, K., \& Wright, M. (2006). Computer gaming and interactive simulations for learning: A meta-analysis. Journal of Educational Computing Research, 34(3), 229-243. https://doi.org/10.2190/FLHV-K4WA-WPVQ-HOYM 